\title{
Interaction Effect of Empathy and Effortful Control on Preschoolers' Prosocial Behavior: Differences Between 4 and 5-Year-Olds
}

\author{
Sori Mok ${ }^{1}$, Min Ju Kang ${ }^{2}$ \\ Assistant Researcher, Human Life Researcher Center, Yonsei University, Seoul, Korea ${ }^{1}$ \\ Associate Professor, Department of Child \& Family Studies, Yonsei University, Seoul, Korea ${ }^{2}$ \\ 유아의 친사회적 행동에 대한 공감능력과 의도적 통제의 상호작용 효과 : \\ 만 4, 5세 연령 차이를 중심으로 \\ 목소리 ${ }^{1}$, 강민주 ${ }^{2}$ \\ 연세대학교 휴먼라이프 연구센터 보조연구원,
}

Objectives: To examine the interaction effect of empathy and effortful control on prosocial behavior among Korean preschoolers.

Methods: The participants of this study were 167 ( 82 boys, 85 girls) 4 and 5-year-olds from preschools in Seoul Province. Prosocial behavior was evaluated based on teachers' reports. The level of empathy was measured by a task in which the children responded to the researcher's questions and effortful control was assessed by behavioral tasks administered by the researcher. The data were preliminarily analyzed by $t$-tests and Pearson's correlation analyses. The interaction effect of empathy and effortful control was analyzed with the SPSS 24.0 PROCESS MACRO.

Results: First, the empathy and effortful control scores of the 5-year-olds were higher than those of the 4-year-olds, whereas there was no age difference in prosocial behavior. Second, in both 4 and 5 year-olds, empathy and effortful control were positively associated with prosocial behavior. Additionally, only for the 5-year-olds, girls demonstrated more prosocial behavior than boys. Third, for explaining the variance in prosocial behavior, there was a main effect of empathy for the 4-year-olds and a main effect of effortful control for the 5-year-olds. Finally, the interaction effect of empathy and effortful control on prosocial behavior was significant only for the 5-year-olds.

Conclusion: The results of this study suggest that as children grow older, empathy contributes to increased prosocial behavior, especially when the level of effortful control is adequate.

Keywords: prosocial behavior, empathy, effortful control, age difference

\section{Introduction}

출생부터 죽음에 이르기까지 인간은 사람들과의 관계라는 틀 속에서 살아간다. 타인과의 관계 속에서 개인이 사회의 구성 원으로서 특정 역할을 수행하기 위해서는 사회의 규칙과 가

Corresponding Author: Min Ju Kang, Associate Professor, Department of Child \& Family Studies, Yonsei University, 50, Yonsei-ro, Seodaemun-gu, Seoul, Korea

E-mail:mjkang@yonsei.ac.kr
치를 학습하는 사회화 과정이 필요하다. 유아는 이러한 사회 화 과정을 통해 특정 상황에서 적절하게 반응하고 주위 환경 에 효율적으로 대처하는 능력인 사회적 유능성을 발달시킨 다(The Korean Society of Educational Psychology, 2009). Gouley, Brotman, Huang과 Shrout (2008)가 사회적 유능성의 행동적인

(C)The Korean Association of Child Studies

This is an Open Access article distributed under the terms of the Creative Commons Attribution Non-Commercial License (http:// creativecommons.org/licenses/by-nc/4.0) which permits unrestricted noncommercial use, distribution, and reproduction in any medium, provided the original work is properly cited. 
측면으로 언급한 친사회적 행동은 사회 내에서 다른 사람과의 관계를 형성하고 유지하기 위한 긍정적 측면의 사회적 행동 으로써, 타인을 돕기 위한 자발적인 모든 행동으로 정의된다 (Eisenberg, Fabes, \& Spinrad, 2006). 친사회적 행동에는 다른 사 람들에게 도움을 제공하는 돕기, 공유하기, 위로하기 및 협력 하기와 같은 행동 영역이 포함되는데(Moon, 2004), 이처럼 도 움을 주는 행동으로 자신뿐 아니라 타인에게 긍정적인 영향을 미치는 행동 유형을 친사회적 행동이라고 할 수 있다.

대인관계의 폭이 넓어지는 유아기에 경험하는 행동 양식 과 사회적 경험은 이후 맺게 되는 모든 관계의 기초가 되는데 (Kostelnik, Whiren, Soderman, \& Gregory, 2006), 이때 친사회적 행동은 사회생활의 가장 기본이 되는 중요한 요소라고 할 수 있다. McClellan과 Katz (2001)는 건강한 대인관계를 위한 친사 회적 행동이 유아기에 잘 형성되지 못한다면, 청소년이나 성 인이 되었을 때 학교 부적응, 정서 불안정과 같은 사회적 부적 응을 경험할 수 있다고 하였다. 실제로 Ministry of Education and Science Technology (2013)는 유아기 교육과정에서 배려, 존 중, 협력과 같이 대인관계에 필요한 사회적 기술을 배우는 것 은 매우 중요한 부분임을 밝혔다. 즉, 사회에서 긍정적인 대인 관계를 형성하는 데 기초가 되는 친사회적 행동의 형성은 유 아기 필수적인 발달 과업이다. 따라서 올바른 대인관계의 바 탕이 되는 유아기 친사회적 행동의 발달에 도움을 주는 요인 을 밝히는 것이 필요하다.

유아의 친사회적 행동에 영향을 미치는 요인들에는 성별, 연령 등과 같은 생물학적 측면과 정서지능, 공감, 의도적 통제 등과 같은 개인 내적 측면이 있다(H. E. Jang \& Kim, 2017). 친 사회적 행동을 예측하는 주요 요인 중 하나인 공감능력은 단 순한 과정이 아니라 타인의 관점을 수용하여 정서를 공유하 는 내적 과정을 거쳐 다시 자신의 정서로 표현하는 다차원적 인 과정이다(Leiberg \& Anders, 2006). 따라서 공감능력을 각 측면에 따라 다르게 정의하는 것이 아니라 복합개념으로 간주 하여 인지적 - 정서적 - 의사소통적 측면을 모두 고려해야 할 필요가 있다. 이렇듯 복합적인 공감능력은 유아가 자신이 맺 는 또래라는 새로운 관계 속에서 타인을 감정적으로 인식하고 이해하면서 발달한다. Carlo, Mestre, McGinley, Samper, Tur과 Sandman (2012)은 공감능력이 부족할 경우, 타인과 원활한 상 호작용을 하지 못하며 만족스럽지 못한 관계 속에서 발생하는 사회 부적응을 경험하게 될 것이라고 하였다. 이렇듯 공감능 력은 사회적 능력을 형성하기 위해 반드시 필요한 중요 구성 요소임과 동시에 유아의 친사회적 행동 발달에 중요한 발판이 된다(Kwak, 2016).
실제로 유아의 공감능력과 친사회적 행동의 관계를 다룬 연구에서 공감능력이 친사회적 행동 발달에 긍정적인 영향을 미치는 동기 요소임을 밝힌 바 있다(Hoffman, 2008). 또한 만 3 세 유아에게 슬픔, 공포, 기쁨 및 중립적인 4 개의 영상을 보여 주면서 심박동 변화를 지표로 공감을 측정한 Noten, Van der Heijden, Huijbregts, Van Goozen과 Swaab (2019)은 정서적 공감 능력이 높은 유아일수록 사회적 관심이 높으며 문제 행동을 덜 보인다고 밝혔다. 더불어 Lane, Wellman, Olson, LaBounty와 $\operatorname{Kerr}$ (2010)는 유아가 다른 사람들의 신념과 감정을 이해하는 공감능력을 바탕으로 자신의 행동을 사회적으로 승인된 친사 회적 행동으로 조절할 수 있다고 보고하였다. 이처럼 공감능 력은 친사회적 행동에 영향을 미치는 강력한 동기요인이 된다 고 할 수 있다.

최근의 연구들은 유아의 사회 - 정서 - 행동적 발달과 적응 을 위해서는 자신의 행동을 스스로 조절하고 통제하는 능력 이 필요하기 때문에 의도적 통제를 친사회적 행동에 영향을 미치는 주요 예측 변인으로 주목하고 있다(Park \& Park, 2017; Rothbart, Sheese, \& Posner, 2007). 의도적 통제란 실행 주의력 의 효율성으로, 의도적으로 주의를 전환하여 지배적인 반응을 억제하고 하위 지배적인 반응을 활성화하는 기질적 자기조절 능력이다(Rothbart \& Rueda, 2005). 개인이 사회적 상황에서 감정과 행동을 조절하기 위해 필요한 능력인 의도적 통제는 상황에 맞게 주의를 기울이거나 전환하는 주의 조절(attention regulation), 계획적으로 충동적인 감정과 행동을 억제하거 나 활성화하는 억제 통제(inhibitory control)로 구성되어 있다 (Eisenberg et al., 2006).

한편 실행 주의력의 효율성 측면에서 정의되는 의도적 통 제는 신경심리학 연구자들에 의해서도 정의되었다. 실행 주의 력이란 실행 기능 중 개인이 원하는 목표를 달성하기 위해 지 배적인 반응을 억제하고 하위반응을 활성화하고, 계획 및 실 수를 점검하는 상위인지 능력을 의미하며(Koo \& Park, 2018), 이러한 실행 주의력을 효율적으로 조절하며 인지과정을 포 함하는 능력을 의도적 통제라고 할 수 있다(Rothbart \& Bates, 2006). 실제로 Rothbart, Sheese와 Posner (2007)의 연구에서 의 도적 통제는 주의체계의 기능과 관련되어 있으며, 이와 관련 된 전대상피질과 전전두 영역은 주의조절 및 의도적 통제를 측정하는 과제를 실시하는 동안 활성화되는 것이 뇌 영상 연 구에서 밝혀졌다. 선행연구들을 종합하여 보면, 의도적 통제 는 즉각적이고 자동으로 나타나는 자극 또는 반응을 억제하 고, 상황에 맞는 행동을 하기 위해 의도적으로 자신의 주의, 행 동, 정서를 조절하는 의식적인 자기조절 능력을 말한다. 이와 
같이 의도적 통제는 충동적인 반응을 조절하여 상황에 맞게 적응하는 능력과 관련이 있기 때문에(Y. Lee \& Lim, 2014) 유 아가 타인과의 관계를 맺는 데 중요한 역할을 하는 것으로 예 측할 수 있다.

선행연구에 따르면, 의도적 통제의 수준이 높은 유아일수 록 사회적 기술이 더 유능하여 또래에게 잘 수용되고(Valiente, Lemery-Chalfant, \& Swanson, 2010), 사회적으로 더 바람직한 행동을 많이 하는 것으로 나타난(Liew, 2012) 반면, 유아기의 의도적 통제 수준은 사회 정서적 발달과 관련이 있는 것으로 밝혀졌다(Allan \& Lonigan, 2011). 이는 의도적 통제의 수준이 낮은 유아의 경우 타인과 긍정적인 상호작용을 하는데 어려움 이 있다는 것을 예측할 수 있게 한다. 이와 같은 선행연구들은 유아의 사회적 능력과 대인관계능력을 향상하는 데 중요한 내 적 기제인 의도적 통제가 친사회적 행동에 있어 중요 요인임 을 보여주고 있다.

지금까지의 선행연구에 근거해 본다면, 유아가 타인의 감 정 혹은 정서를 이해하고 공유하는 공감능력과 자신의 감정 혹은 행동을 억제하고 활성화하는 의도적 통제는 바람직한 인 간관계 형성에 기초가 되는 친사회적 행동에 필수적인 요인임 을 알 수 있다. 그러나 공감능력이나 의도적 통제만으로는 친 사회적 행동을 동기화할 수 없다는 주장 또한 제기되고 있다. 예를 들면, 만 $3,4,5$ 세 유아를 대상으로 억제, 인지·정서 공감, 친사회적 행동의 발달적 특성을 살펴본 M.-J. Kang (2016)은 만 4, 5세 유아의 의도적 통제의 한 요소인 억제가 친사회적 행동에 영향을 미치지 않았다고 보고하면서 단일 변인이 아닌 다양한 변인들이 서로 연관되어 유아의 친사회적 행동 발달 에 영향을 미칠 수 있기 때문에 후속 연구에서 이를 살펴볼 필 요가 있다고 하였다. 즉, 행동을 조절하고 충동을 억제하는 의 도적 통제만으로 유아의 친사회적 행동이 발달하는 것은 아닐 수 있기 때문에 의도적 통제가 친사회적 행동으로 이어지기 위해서는 다른 요소를 함께 고려할 필요가 있다.

하지만 대부분의 선행연구는 유아의 공감능력과 친사회적 행동 또는 의도적 통제와 친사회적 행동의 직접적인 관계만을 살펴보았을 뿐, 세 변인 간 복합적인 관련성을 검증한 연구는 사실상 많이 부족한 실정이다. 국내 연구에는 유아가 아닌 5, 6학년 초등학생을 대상으로 자기보고식 질문지법을 사용하여 공감능력, 의도적 통제 그리고 친사회적 행동의 구조적 관계 를 살펴본 연구(E. Cho \& Jung, 2014)가 있다. 또한 유아의 공 감, 억제, 친사회적 행동의 관계를 살펴본 연구가 있지만(M.J. Kang, 2016) 친사회적 행동에 미치는 각 변인의 단순 영향력 만을 살펴보았을 뿐, 두 변인이 어떠한 방식으로 유아의 친사
회적 행동에 영향을 미치는지 살펴보지 않았다. 이와 같이 유 아의 친사회적 행동을 살펴본 기존의 선행 연구들은 사회적 능력인 친사회적 행동을 설명하는 데 있어 공감능력, 의도적 통제와 같은 개인 내적 요인을 구분하여 살펴보았다.

그러나 Y. Lee와 Lim (2014)은 유아의 발달은 단일 요인에 의해서만 이루어지는 것은 아니며 요인들이 상호작용하여 유 아의 친사회적 행동에 더 크게 영향을 미친다고 보고하였다. Y. H. Kwon (2014)은 유아의 수줍은 특성이 사회적 유능성의 발달에 부정적 영향을 미칠 수 있지만, 이때 높은 의도적 통제 수준이 이를 완화할 수 있다고 보고하였다. 또한, 의도적 통제 의 구성 요소를 밝힌 Rothbart 등(2007)에 의하면 높은 의도적 통제 수준을 가지고 있는 5세 유아의 경우, 타인의 상황에 대 한 감정과 행동을 조절할 수 있는 능력을 바탕으로 자신의 정 서를 타인 지향적으로 조절할 수 있기 때문에 대인관계에 있 어서 사회화가 잘 이루어진다고 하였다. 이를 바탕으로 유아 의 공감능력과 의도적 통제는 서로 상보적인 역할을 담당하여 유아에게 나타나는 행동적 측면, 그 중에서도 친사회적 행동 에 중요한 역할을 할 것으로 추론할 수 있다.

이처럼 본 연구에서 공감능력과 의도적 통제의 상호작용 모형으로 연구 문제를 살펴본 이유는 유아가 타인과의 관계 에서 친사회적인 행동을 하도록 발달하는 경로에 있어 기질 적 성향인 의도적 통제가 높고 낮은 정도에 따라 공감능력 수 준과 어떻게 상호작용하여 그 효과가 발현되는 것인가를 밝힘 으로써 각 유형에 따른 발달을 예측하고 중재 시 근거 자료로 활용하기 위함이다. Y. H. Kwon (2014)은 수줍음이 많은 유아 가 사회적 집단에 적응함에 있어서 어려움을 겪을 때 높은 의 도적 통제 수준이 이를 완화할 수 있다고 보고하였고, Allan과 Lonigan (2011)은 높은 의도적 통제의 수준을 가지고 있는 유 아의 경우 타인에게 공감과 감정이입을 잘하며 이를 바탕으로 유아의 사회화 발달이 이루어진다고 밝혔다. 더불어 Eisenberg 등(2007)은 일반적으로 공감능력과 의도적 통제는 정적 상관 이 있지만, 의도적 통제 수준이 낮더라도 공감능력이 높은 유 아의 경우 높은 공감능력이 사회적 관계가 원활할 수 있도록 도와준다고 하였다.

반면, Bae와 Lim (2012)은 의도적 통제의 수준이 높은 유아 는 다른 사람의 힘든 상황을 보고 본인의 정서를 억제하고 타 인의 감정에 초점을 맞추기에 타인을 이해하며 타인 지향적인 행동을 할 수 있다고 밝혔다. 즉, 의도적 통제가 높은 유아는 자신에게 각성된 높은 수준의 정서를 억제하고 다른 사람에게 주의를 돌릴 수 있는 능력으로 발전될 경우 타인의 정서에 공 감할 수 있는 공감능력과 상호작용하여 그들에게 필요한 사회 
적 기술을 더 활성화 할 수 있도록 유도할 수 있다. 그러나 즉각 적이고 자동적으로 나타나는 우세한 반응을 억제하고, 상황에 맞는 행동을 하기 위해 의도적으로 자신의 주의, 행동, 정서를 조절하는 능력인 의도적 통제가 높다고 하여 반드시 타인의 관 점에서 느끼는 정서를 정확하게 지각하고 그 정서를 내적으로 함께 느끼어 표현하는 능력이 동시에 발달되는 것은 아니다. 이러한 이론적 근거를 바탕으로 본 연구에서는 친사회적 행동 을 이해하고 설명하는 데 있어 유아 개인 내적 요인인 공감능 력과 의도적 통제 간 상호작용 효과를 살펴보고자 한다.

한편, 지금까지 유아의 친사회적 행동에 대한 연구에서 연 령에 따른 차이가 있으며 특히 연령이 높을수록 친사회적 행 동을 더 많이 한다는 연구결과가 보고된 바 있다(Y. Jang, Kang, $\& \mathrm{Kim}, 2003)$. 이에 대해 Hoffman (2002)은 연령이 높아짐에 따라 친사회적 행동이 증가하는 이유는 사회인지적 능력의 발 달과 모방학습, 직접적인 지도의 기회 등이 많아지고 사회적 상호작용을 통하여 자기중심적인 사고가 줄어들어 점차 타인 의 입장을 이해하기 때문이라고 주장하였다. 더불어 유아의 친사회적 행동을 연구한 연구들(M.-J. Kang, 2016; Libermann, 2007)에서 단일 연령이 아닌 만 3-5세의 유아를 대상으로 하 고 있으며, 연령별 친사회적 행동의 차이를 살펴본 M.-J. Kang (2016)의 연구에서 연령 간 유의한 수준에서 차이가 있다는 점 을 통해 공감능력, 의도적 통제 및 친사회적 행동의 관계에 있 어서 연령에 따른 차이가 나타날 가능성이 있다고 판단하였 다. 하지만 선행연구에 따르면(Koo \& Park, 2018), 만 3세 유아 는 다른 연령에 비해 언어적 이해능력이 부족하기 때문에 면 접에서 내용을 이해하는 데 어려움이 있는 것으로 나타나 제 외하였다. 이에 친사회적 행동에 대한 관련 변인의 영향과 그 중요성에 있어서 만 4, 5세 유아를 대상으로 연령에 따른 친사 회적 행동의 차이를 살펴보는 것은 의미가 있다.

따라서 본 연구에서는 만 4,5 세 유아를 대상으로 친사회적 행동 발달에 대한 공감능력과 의도적 통제의 영향을 살펴보 고 인지·정서적인 측면을 모두 포함하는 유아의 공감능력과 기질적 측면인 의도적 통제와 상호작용함으로써 친사회적 행 동에 어떠한 영향을 미치는지 만 4세 유아 집단과 만 5세 유아 집단으로 구분하여 알아보고자 한다.

한편, 유아의 친사회적 행동에 영향을 미치는 요인은 크게 유아의 개인 요인과 환경적 요인으로 볼 수 있다(K.-S. Chung $\&$ Lee, 2017). 개인 요인에는 연령(M.-J. Kang, 2016), 성별 (Moon, 2004) 등이 포함되며 환경적 요인에는 교육기관의 환 경 등이 포함된다. 유아의 친사회적 행동에 영향을 미치는 교 육기관의 환경적 요인으로는 하루 평균 보육시간(S.-H. Kim,
2015) 등이 있다. 유아의 성에 따라 친사회적 행동의 차이가 있음을 보고한 선행 연구 결과를 토대로 성별을 통제변인으로 포함시키고(Seo, Beon, \& Ha, 2016; Song \& Jang, 2015), 유치원 운영시간에 따른 반일제와 종일제 유아의 문제 행동의 유의 한 차이가 있다는 Hwang (2010)의 연구결과를 바탕으로, 8시 간을 기준으로 구분하여 차이를 살펴보고자 한다. 또한 Korea Institute of Child Care and Education (KICCE; 2016)은 미국의 National Accreditation of Education for Young Children (NAEYC), 덴마크, 아이슬란드의 국가별 4-6세 반의 교사 대 유아 비율을 비교하여 $1: 10$ 이 세계적 구성 기준에 적절하게 대응될 것이라 보고하였다. 이에 본 연구에서는 $1: 10$ 교사 대 유아 비율을 기 준으로 두 집단으로 구분하여 친사회적 행동의 차이가 있는지 알아보고자 한다. 이와 같이 본 연구에서는 친사회적 행동과 관련이 있을 수 있는 형제 유무(H.-S. Kim, 2010) 하루 평균 보 육시간(S.-H. Kim, 2015), 교사 대 유아 비율(KICCE, 2016)을 함께 살펴보고 관련이 있는 변인은 통제한 후 공감능력 및 의 도적 통제의 주 효과, 상호작용효과를 살펴보고자 한다.

본 연구의 결과는 유아의 건강한 사회성 발달에 영향을 미 치는 공감능력의 중요성 및 의도적 통제의 역할과 친사회적 행동의 발달적 변화를 이해하여 연령에 맞게 유아의 친사회적 행동을 증진시키는 프로그램의 개발에 기초자료가 될 것으로 기대한다. 이를 바탕으로 유아의 친사회적 행동의 증진을 위 해 노력한다면, 그들이 건강한 사회 구성원으로 성장하는 데 도움을 제공할 수 있을 것이다.

\section{연구문제 1}

만 4, 5세 유아의 사회 인구학적 변인 및 기관 경험의 특성에 따른 친사회적 행동의 차이가 있는가?

\section{연구문제 2}

유아의 친사회적 행동에 대한 공감능력과 의도적 통제의 주 효과와 상호작용 효과는 만 4,5 세 유아의 연령에 따라 어떠 한가?

\section{Methods}

\section{연구대상}

급변하는 시대 속에서 여성의 경제 활동 증가, 자녀 수 감소, 조기 교육의 중요성 인식 증가 및 만 0-5세 무상보육 정책에 
따른 유아의 교육기관 이용률이 2015년 21.4\%에서 2018년 $25.2 \%$ 로 증가(Ministry of Health \& Welfare [MOHW], 2018)하 여 부모 외의 성인 및 또래와의 관계를 형성하고 확장할 수 있 는 시기가 앞당겨졌다(Yoon, 2015). 이에 따라 기관에서 또래 유아들과 경험할 수 있는 다양한 활동이 유아의 친사회적 행 동에 미치는 영향력을 간과할 수 없게 되었다. 이와 같이 현재 보육기관은 부모의 근로 형태 혹은 시간을 고려하여 정규 운 영 시간을 외 시간 연장 보육, 야간 보육, 24 시간 보육, 휴일 보 육 등 다양한 형태로 운영하고 있다(MOHW, 2018). 이와 같 이 유아들이 기관에서 머무르는 양적 시간이 증가하면서 그들 이 어린이집에서 보내는 물리적 시간이 그들의 발달에 어떠 한 영향을 미치는지에 대한 연구가 진행되고 있다(S.-H. Kim, 2105). 실제로 S. Choi (2014)는 시간 연장 보육에 참여하는 유 아들이 정규반 유아들에 비해 내재적, 외현적 문제행동을 많 이 보인다고 하였으나, 스트레스 호르몬을 중심으로 기관 이 용시간을 살펴본 KICCE (2012)는 비록 유아의 기관 이용시간 이 길더라도 양질의 보육 서비스와 안정적인 가정 환경이 뒷 받침 된다면 유아의 사회.정서적 행동과 발달수준이 그들보 다 일찍 귀가하는 유아보다 상대적으로 높게 나타났다고 보고 하였다. 이처럼 하루 평균 보육 시간이 유아의 친사회적 행동 에 부정적 또는 긍정적으로 영향을 미칠 수 있기에 본 연구에 서는 하루 평균 보육 시간을 통제변인으로 하여 유아의 친사 회적 행동의 개인차를 설명할 수 있는 다른 요인 간 상호작용 을 분석하고자 한다.

이에 본 연구에서는 서울시에 소재하고 있는 네 곳의 직장 어린이집과 한 곳의 민간유치원을 임의로 선정하여 총 13학 급에 재원 중인 만 4,5 세 유아 총 188 명 중 보호자에게 연구에 대한 설명 후, 연구 참여를 동의한 177 명을 대상으로 친사회 적 행동을 각 학급의 교사 13 명이 교사 1 명당 평균 13-14명의 유아를 평정하였고, 그 중 면접 당일 결석한 6명, 진행 중 그만 하고 싶다고 한 4 명을 제외한 167 명을 최종 연구 대상으로 하 여 분석을 실시하였다. 성별에 따른 연구 대상의 수는 남아 82 명과 여아 85명, 연령별 연구 대상 수는 만 4세 77명과 만 5세 90 명이었다. 대상 유아의 연령은 만 4 세의 경우 평균 53.99 개 월 $(S D=3.26)$, 만 5 세는 평균 65.89 개월 $(S D=3.32)$ 이었다.

\section{연구도구}

유아의 친사회적 행동은 담임교사의 평정에 의한 질문지로 측 정하였으며, 공감능력과 의도적 통제는 연구자가 유아와 개별 면접을 실시하여 측정하였다.

\section{친사회적 행동 척도}

유아의 친사회적 행동은 Y.-O. Kim (2003)이 개발한 유아의 친 사회적 행동평가 척도를 Seo (2006)가 재구성한 교사용 친사 회적 행동 평가 척도(Prosocial Behavior Scale for Young Children [PBSYC])를 사용하여 측정하였다. Y.-O. Kim (2003)의 척도는 유아의 자유로운 놀이상황에서 나타나는 친사회적 행동을 측 정하기 위해 개발되었으며 만 4,5 세 유아들을 대상으로 척도 의 신뢰도와 타당도를 검증하였다.

본 척도는 나누기(3문항), 도움주기(3문항), 감정이입과 조 절하기(4문항), 지도성(4문항)으로 구성된 총 14 문항의 척도 이다. 각 반의 담임교사는 평소 유아의 행동을 근거로 각 문 항에 대하여 전혀 그렇지 않다(1점), 그렇지 않다(2점), 보통 이다(3점), 대체로 그렇다(4점), 항상 그렇다(5점) 등과 같이 5 점 척도로 응답하도록 되어 있다. 유아가 받을 수 있는 총점은 0-60점이며, 점수가 높을수록 유아의 친사회적 행동이 높다 는 것을 의미한다. 본 연구에서 측정된 친사회적 행동 총점의 Cronbach's $\alpha$ 는 .90이었다.

\section{유아의 공감능력 검사 도구}

유아의 공감능력을 측정하기 위해 Bryant (1982)가 초등학교 아동을 대상으로 개발한 ‘공감능력 검사도구’를 참고하여 Yeon (1988)이 제작하고 유아에게 적합하게 수정한 S. Choi (2002) 의 도구를 사용하였다. 질문에 대한 유아의 이해를 높이기 위 해 M.-J. Kang과 Sim (2011)은 각 질문 문항에 해당되는 그림 카드를 제작하여 사용하였다. 이에 본 연구에서도 그림카드를 사용하였으며 실험자가 유아에게 그림카드를 보여주고 질문 하는 형식으로 공감능력을 측정하였다.

유아의 공감능력 검사 도구는 슬픔, 심적 부담, 기쁨, 불안 의 4 가지 하위 영역이 슬픔 요인 3 문항을 제외하고 각각 5 문 항씩으로 총 18문항으로 구성되어 있다. 채점은 Likert식 3점 척도이며, 그렇지 않다(1점), 그저 그렇다(2점), 매우 그렇다(3 점)로 구분하였다. 유아가 받을 수 있는 총점은 18-54점이며, 점수가 높을수록 유아의 공감능력이 높음을 의미한다. 본 연 구에서는 공감능력의 하위요인 중 슬픔 요인을 구성하는 총 3 문항의 내적합치도가 낮아 해당되는 3 문항을 제외하고 총 15 문항을 사용하여 유아의 공감능력을 측정하였다. M.-J. Kang 과 $\operatorname{Sim}$ (2011)의 연구에서 공감능력의 전체 Cronbach's $\alpha$ 는 .68 이었으며, 본 연구에서 사용하는 공감능력 총점의 Cronbach's $\alpha$ 는 .62로 나타났다. 


\section{유아의 의도적 통제 검사 도구}

유아의 의도적 통제 평가는 부모나 교사의 보고에 의한 질문지 측정 또는 유아의 행동을 직접 관찰할 수 있는 행동 과제를 통 해 수행되고 있다. 연구에 따라 질문지 측정과 행동 과제에 의 한 측정 간의 일치성은 차이가 있는 것으로 나타났다. 질문지 측정과 행동 과제에 따른 의도적 통제 측정 간의 상관이 유의 하게 나타난 국외 연구들(Kochanska, 2002; Spinrad et al., 2007) 과 달리 국내 연구자인 Moon (2004)과 Bae와 Lim (2012)은 측 정 방법에 따른 의도적 통제의 측정 간의 관련성은 없거나 적 은 것으로 나타났다고 보고하였다. 질문지법과 행동 과제 측정 으로 나타난 결과의 관련성이 낮을 경우, 각기 다른 방법으로 측정한 결과에 대해 어떻게 해석하고 통합할지에 대한 문제가 나타날 수 있다. 따라서 의도적 통제를 즉각적이고 자동적으로 나타나는 우세한 반응을 억제하고, 상황에 맞는 행동을 하기 위해 의도적으로 자신의 주의, 행동, 정서를 조절하는 능력이 라고 정의한 본 연구에서는 유아의 행동을 직접 관찰하여 의도 적 통제를 측정할 수 있는 행동 과제를 사용하고자 한다.

유아의 의도적 통제는 연구 대상과 목적에 따라 다른 과제 들로 측정되고 있으며, Murray와 Kochanska (2002)는 요인분 석 결과, 의도적 통제는 신체운동 조절하기와 지시에 따라 행 동을 조절하기가 주요 요인이라고 보고한 바 있다. 그러나 국 내 연구(H. S. Kim, 2015)에서는 신체운동 조절하기의 행동 과 제가 부모나 교사가 질문지를 통해 보고한 의도적 통제와는 관련이 없다고 보고하였다. Zhou, Chen과 Main (2012)은 의도 적 통제 행동 과제 목록 중 주의를 조절하는 것과 동시에 행동 을 활성화하거나 억제하는 능력을 측정할 수 있는 과제인 적 록실험과제와 머리-발-무릎-어깨 과제를 소개하였다. 유아의 의도적 통제를 측정하는 '머리-발-무릎-어깨(head-toes-kneesshoulders) 과제(Lengua et al., 2015)'는, 유아의 의도적 통제를 쉽게 측정할 수 있는 과제로, 주의를 조절하여 지시에 따라 행 동을 조절하는 능력을 평가할 수 있다(Ji \& Lee, 2009).

또한 이 과제는 유아에게 익숙한 대근육 운동을 바탕으로 조절능력을 측정할 수 있는 장점을 가지고 있다. 이와 같은 실 험법은 유아의 행동에서 나타난 의도적 통제를 평정자가 직접 관찰하여 평가할 수 있다는 장점을 가지고 있다. 이를 바탕으 로 Koo와 Park (2018)은 행동 과제 평정 간에 관련성이 높은 두 과제의 평균값을 사용하여 의도적 통제를 측정한 바 있다. 이 에 따라 본 연구는 행동 과제 측정의 변별력을 높이기 위해 본 연구 대상 연령에 적합하도록 적록실험과제를 “뽀로로-크롱 과제'로 변형하였고, 머리-발-무릎-어깨 과제를 사용하여 두
과제의 평균값을 유아의 의도적 통제 점수로 사용하였다.

뽀로로-크롱 과제 첫 번째 선정한 뽀로로-크롱 과제는 Murray 와 Kochanska (2002)의 연구에 사용된 '적록신호 과제(red-green sign)'를 선행연구(Koo \& Park, 2018)와 예비조사 결과를 바 탕으로 본 연구에 적합하게 수정·보완한 과제이다. Murray와 Kochanska (2002)의 의도적 통제를 측정하기 위한 다양한 과 제 중 적록신호 과제는 신호에 따라 지배적인 반응을 억제하 고 비지배적인 반응을 활성화시키는 능력을 평가하기 위한 것 이다. 유아의 흥미를 유발하기 위하여 아동학 전공 교수 1 인의 자문을 받아 국내 실정에 맞게 뽀로로-크롱 과제로 수정하여 사용하였다.

머리-발-무릎-어깨 과제 두 번째 과제인 머리-발-무릎-어깨 과제는 McClelland 등(2007)이 머리-발 과제(head-to-toes task) 로 개발한 도구를 Ponitz 등(2008)이 확장한 것이다. 머리발-무릎-어깨 과제는 유아의 의도적 통제 능력의 세 가지 측 면인 주의(attention), 억제통제(inhibitory control), 작업 기억 (working memory)을 통합하여 측정할 수 있는 게임 형식의 도 구이다(Ji \& Lee, 2009). 본 과제에서 유아는 정해진 규칙에 따 라 실험자가 말하는 신체부위와는 다른 신체부위를 만져야 한다.

기존의 머리-발 과제의 경우, 1-2단계로 규칙이 단순하여 연령이 증가할수록 변별력이 떨어지는 단점이 있기 때문에, 만 5세 이후의 유아를 대상으로 과제를 진행할 경우, 기존의 도구에서 제시한 규칙보다 많은 수의 규칙을 포함하여 진행할 필요가 있다고 판단되었다(Ji \& Lee, 2009; Koo \& Park, 2018; Ponitz et al., 2008). 따라서 만 4, 5세를 대상으로 하는 본 연구 에서는 규칙의 수를 증가하여 3단계 난이도로 구성된 머리발-무릎-어깨 과제(McClelland et al., 2007)를 사용하여 의도적 통제 능력을 측정하였다.

유아기 동안 의도적 통제는 급격한 발달이 이루어지기 때 문에 만일 유아의 월령을 고려하지 않은 쉬운 과제 또는 어려 운 과제로 의도적 통제를 측정할 경우, 천정효과나 바닥효과 가 발생할 수 있다(Koo \& Park, 2018). 따라서 본 연구에서는 이를 방지하기 위해 만 4, 5세 유아의 발달 특성을 고려하여 적절한 난이도가 부여된 두 가지의 행동 과제를 통해 측정 도 구의 변별력을 높였다. 뽀로로-크롱 과제와 만 5 세 유아의 연 령을 고려하여 규칙을 추가한 머리-발-무릎-어깨 과제간의 상 관관계를 알아보기 위해 Pearson의 적률상관계수를 산출한 결 과 $r=.41(p<.01)$ 로 나타났다. 본 연구에서 의도적 통제의 점 
수는 두 과제의 평균값으로 사용하였으며, 두 과제의 수행능 력으로 구성된 의도적 통제의 점수가 높을수록 유아가 주의를 조절하며 행동을 억제하고 활성화하는 능력이 뛰어남을 의미 한다.

\section{연구절차}

유아의 담임교사에게 사전에 연락한 후 방문하여 본 연구의 목적, 방법, 절차 등을 충분히 설명한 뒤, 기관과 교사로부터 연구 참여에 동의를 받은 경우 교사용 친사회적 행동 평가 척 도를 배부하였다. 교사용 친사회적 행동 평가 척도는 본 연구 자가 기관을 방문하여 직접 수거하였다. 이 후 오전 자유놀이 시간에 기관의 조용한 공간에서 유아의 공감능력과 의도적 통 제를 측정하기 위한 유아면접을 $1: 1$ 면접방식으로 진행하였 다. 면접을 시작하기 전, 연구자는 유아와 약 1-2분 간 일상적 인 대화를 나누며 유아가 낮선 상황에 적응할 수 있도록 한 후 검사를 실시하였다. 먼저, 공감능력 검사는 연구자가 유아에 게 그림카드를 보여주며 질문하는 형식으로 진행하고, 의도적 통제 과제는 뽀로로-크롱 과제를 먼저 하고 머리-발-무릎-어 깨 과제를 실시하였으며 유아의 응답은 검사지에 즉각 기록하 였다. 두 개의 의도적 통제 과제를 실시하는데 유아별로 평균 12 분 정도 소요되었다.

\section{자료분석}

연구를 위해 수집된 자료는 SPSS WIN 24.0 (IBM Co., Armonk, NY) 프로그램을 사용하여 다음과 같은 방법으로 분 석하였다. 첫째, 만 4, 5세 유아의 친사회적 행동이 성별, 출생 순위, 보육시간, 교사 대 유아 비율에 따라 유의하게 차이가 있 는지를 $t$ 검정을 통해 살펴보았다. 만 4,5 세 유아의 친사회적 행동과 공감능력, 의도적 통제의 일반적 경향을 살펴보기 위 해 각 측정 변인 별로 평균과 표준편차를 산출하였으며, 연령 집단에 따른 $t$ 검정을 실시하였다. 회귀분석을 하기 전, 측정 변인들 간의 관계를 살펴보고자 Pearson의 적률상관분석을 실 시하였다.

둘째, 유아의 친사회적 행동에 대한 공감능력과 의도적 통 제의 상호작용 효과를 검증하기 위해 Hayes (2013)가 개발한 SPSS MACRO 프로그램인 PROCESS를 활용하였다. PROCESS 는 담임교사 1 명이 여러 유아를 평정했을 때 나타날 수 있는 내 재적 자료(nested data)의 문제점을 bootstrap 방법을 이용하여 보완할 수 있다(Hayes, 2013). 또한 변인 간의 구체적인 상호작
용을 살펴보기 위해 평균 지점과 $\pm 1 S D$ 지점에서의 유의성을 검 증하였으며, 상호작용 변인인 의도적 통제의 어느 값에서 종속 변인에 대한 독립변인의 조건부 효과(conditional effect)가 유의 한지 확인하기 위해 존슨-네이만(Johnson-Neyman) 방법을 활 용하였다(Johnson \& Neyman, 1936). PROCESS는 상호작용 효 과 검증 시 존슨-네이만 기법을 수행할 수 있다는 장점을 가지 고 있다. Hayes (2013)는 종속변인에 영향을 미치는 상호작용 변인들의 다중공선성을 줄이기 위한 방법으로 알려진 평균중 심화(mean centering)가 실제 변인 간의 공차를 크게 변화시키지 않는다고 밝혔다. 이에 본 연구에서는 모든 변인에 대하여 평균 중심화를 실시하지 않았다.

\section{Results}

\section{측정변인들의 일반적 경향과 유아 및 기관의 특성에 따른 차이 검정}

연령을 구분하여 성별, 유아의 출생 순위, 기관 종류, 하루 평 균 보육시간, 교사 대 아동 비율에 따른 친사회적 행동에 차이 가 있는지 분석해 본 결과 Table 1 과 같다. 그 결과 만 5 세 유아 에게서 성별에 따른 친사회적 행동의 유의미한 차이 $(t=-2.06$, $p<.01)$ 가 나타났으며, 그 이외에는 만 4, 5세 유아 모두 출생 순위 및 기관 경험의 특성에 따른 친사회적 행동에 차이가 유 의미하게 나타나지 않았다. 이에 본 연구에서는 성별을 통제 한 후, 유아의 친사회적 행동에 대한 공감능력과 의도적 통제 의 주효과와 상호작용 효과를 검증하였다.

다음으로 친사회적 행동에 대해 공감능력과 의도적 통제가 어떠한 방식으로 영향을 미치는지를 연령에 따라 살펴보기 위 한 사전검사로 연구변인들에 대한 연령 차이를 본 결과는 다 음과 같다(Table 2). 우선 교사가 평정한 친사회적 행동의 평균 을 살펴보면, 60점 만점에서 만 4세 유아는 $48.57(S D=9.44)$, 만 5세 유아는 $48.18(S D=6.67)$ 로 나타났다. 5점 척도의 문 항평균 점수로 환산하면 만 4세 유아가 3.47점, 만 5세 유아가 3.44점으로 5점 척도 중 보통이다(3점)보다 높은 수준에 해당 하는 점수이다. 이는 본 연구에 참여한 만 4,5 세 유아 모두 친 사회적 행동 수준이 보통보다 높은 편임을 의미한다. 친사회 적 행동 수준에 대한 연령 차이를 살펴보기 위해 $t$ 검정을 실시 한 결과, 통계적으로 유의하지 않았다.

다음으로 공감능력의 점수의 평균은 45점 만점에서 만 4 세 유 아가 $37.94(S D=3.94)$, 만 5세 유아가 $39.36(S D=4.15)$ 으로 나왔 
Table 1

T-Test for Prosocial Behavior According to the Preshoolers' Characteristics

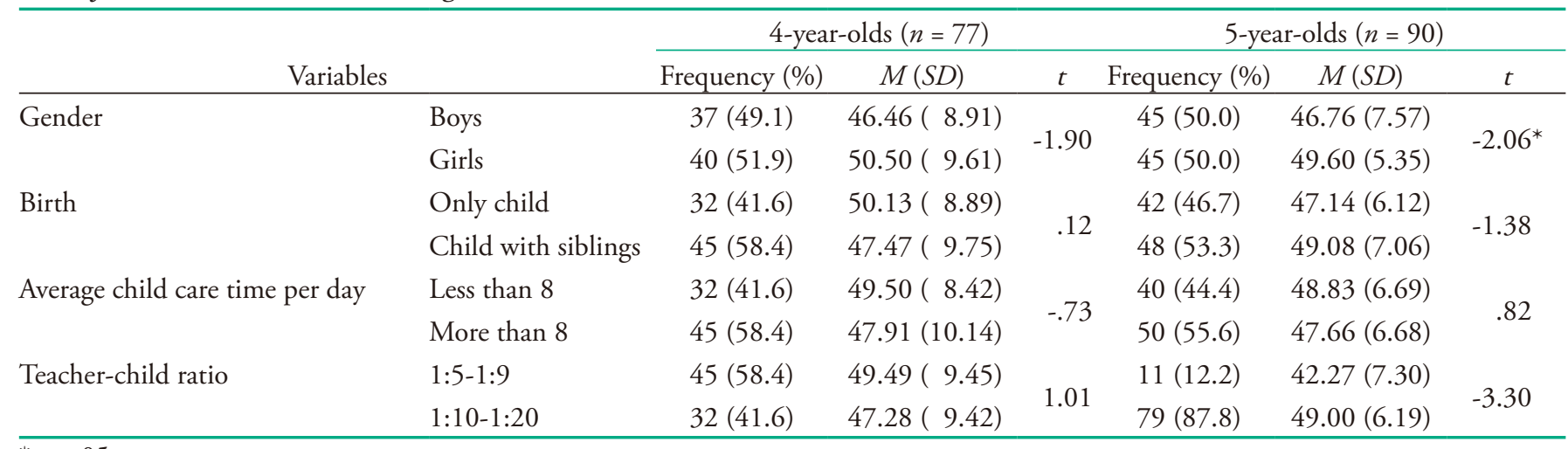

${ }^{*} p<.05$.

Table 2

Descriptive Statistics and T-Test by Age Difference for the Measured Variables

\begin{tabular}{|c|c|c|c|c|c|c|c|c|c|}
\hline \multirow[b]{2}{*}{ Variables } & \multirow{2}{*}{$\begin{array}{c}\text { Possible } \\
\text { score range }\end{array}$} & \multirow{2}{*}{$\begin{array}{c}\text { Actual } \\
\text { score range }\end{array}$} & \multicolumn{3}{|c|}{ 4-year-olds $(n=77)$} & \multicolumn{3}{|c|}{ 5-year-olds $(n=90)$} & \multirow{2}{*}{$t$} \\
\hline & & & $M(S D)$ & Skewness & Kurtosis & $M(S D)$ & Skewness & Kurtosis & \\
\hline Prosocial behavior & $0-60$ & $31-58$ & $48.57(9.44)$ & -.01 & -.73 & $48.18(6.67)$ & -.36 & .36 & .31 \\
\hline Effortful control & $0-44$ & $5 \sim 43.5$ & $22.25(7.46)$ & .11 & -.72 & $31.24(5.87)$ & -.49 & -.10 & $-8.62^{* * *}$ \\
\hline
\end{tabular}

${ }^{*} p<.05 .{ }^{* * *} p<.001$.

Table 3

Correlation Coefficients Among the Measured Variables

\begin{tabular}{lccc}
\hline & 1 & 2 & 3 \\
\hline 1. Prosocial behavior & - & $.31^{* *}$ & $.24^{*}$ \\
2. Empathy & $.28^{* *}$ & - & .20 \\
3. Effortful control & $.41^{* *}$ & $.22^{*}$ & - \\
\hline
\end{tabular}

Note. Diagonal top $(n=77)$ of 4 -year-olds and diagonal bottom $(n=90)$ of 5 -year-olds.

${ }^{*} p<.05 .{ }^{* *} p<.01$.

다. 공감능력에 있어 연령차를 알아보기 위하여 $t$ 검정을 실시한 결과 만 5세 유아의 공감능력 수준이 만 4세 유아의 공감능력 수 준보다 유의하게 높은 것으로 나타났다 $(t=-2.26, p<.01)$.

마지막으로 의도적 통제 점수는 최소 5점에서 최대 43.5 점으로 분포하며, 평균은 44점 만점에서 만 4세 유아가 22.25 $(S D=7.46)$, 만 5세 유아가 $31.24(S D=5.87)$ 로 나왔다. 이러한 결과는 만 5 세보다 만 4 세 유아의 의도적 통제 수준의 개인차 가 크다는 것을 알 수 있으며 $t$ 검정 결과, 만 5 세 유아의 의도 적 통제 수준이 만 4세 유아의 의도적 통제수준보다 통계적으 로 유의하게 높은 것으로 나타났다 $(t=-8.62, p<.001)$.

본 연구는 만 4,5 세 유아를 대상으로 공감능력이 친사회적 행동에 미치는 영향과 의도적 통제의 상호작용 효과가 있는지
를 검증하였다. 이를 위한 회귀분석의 기초분석으로써 측정한 변인들 간의 상관관계를 알아보기 위하여 Pearson의 적률상관 계수를 산출하였다(Table 3).

먼저, 만 4세 유아의 공감능력과 친사회적 행동 간의 관계 에서 정적인 상관을 보였으며 $(r=.31, p<.01)$, 만 5 세의 유아 에게도 정적 상관이 나타났다 $(r=.28, p<.01)$. 이는 공감능력 의 수준이 높을수록 친사회적 행동을 더 많이 한다는 것을 의 미한다. 두 번째로, 의도적 통제와 친사회적 행동의 관계에서 만 4세 유아 $(r=.24, p<.05)$ 와 만 5 세 유아 $(r=.41, p<.01)$ 모 두에게 정적인 상관이 나타났다. 이를 통해 만 4,5 세 유아의 의도적 통제 수준이 높을수록 친사회적 행동을 더 많이 한다 는 것을 알 수 있다. 
Table 4

Main and Interaction Effect of Empathy and Effortful Control on Prosocial Behavior Among 4-Year-Olds

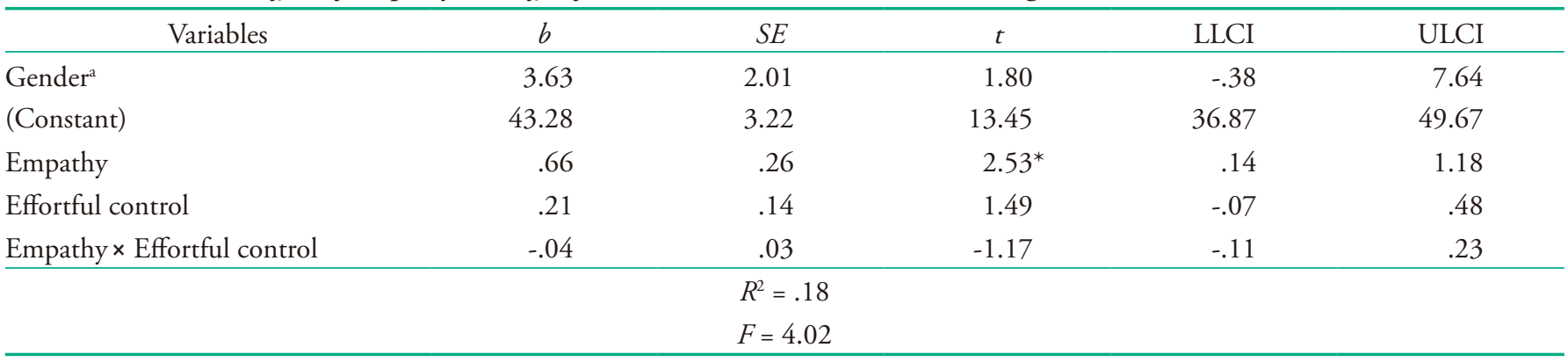

Note. $n=77$.

${ }^{\mathrm{a}}$ Gender is boys $=0$, Girls $=1$ dummy code.

${ }^{*} p<.05$.

Table 5

Main and Interaction Effect of Empathy and Effortful Control on Prosocial Behavior Among 5-Year-Olds

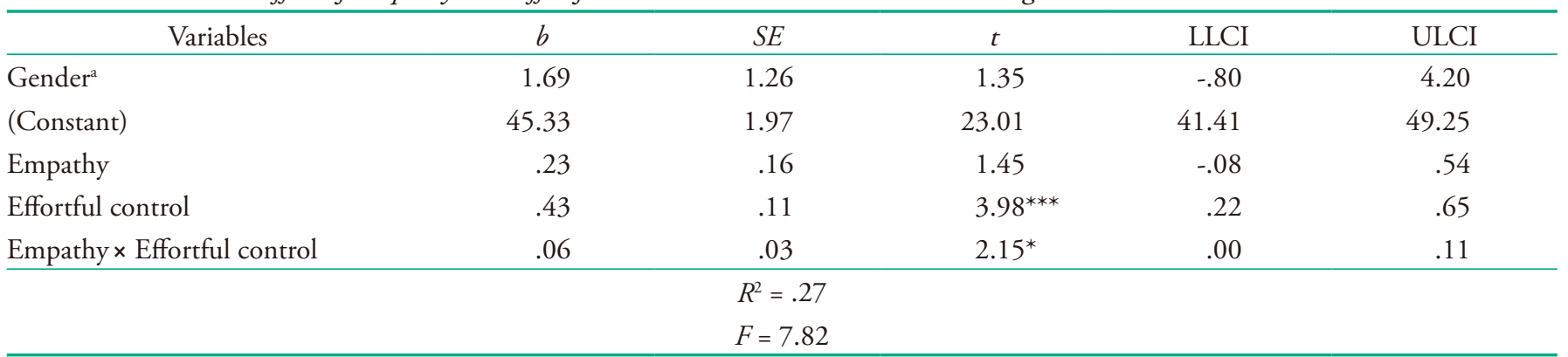

Note. $n=90$.

${ }^{\mathrm{a}}$ Gender is boys $=0$, Girls $=1$ dummy code.

${ }^{*} p<.05 .{ }^{* * *} p<.001$.

\section{만 4,5 세 유아의 친사회적 행동에 대한 공감능 력과 의도적 통제의 주 효과와 상호작용 효과}

만 4세 유아의 친사회적 행동에 대한 공감능력의 주효과 $(t=$ $2.53, p<.05)$ 만 유의하게 나타나 공감능력이 친사회적 행동에 유의한 정적 영향을 미치는 것을 알 수 있었다(Table 4). 즉, 만 4세 유아의 친사회적 행동을 예측해 줄 수 있는 변인은 공감능 력이 유일하였다. 이는 만 4세의 공감능력의 수준이 높을수록 친사회적 행동을 더 많이 한다는 것을 의미한다. 그러나 공감 능력과 의도적 통제의 상호작용효과는 $95 \%$ 신뢰구간에서 하 한값(LLCI)과 상한값(ULCI) 사이에 0 을 포함하여 통계적으로 유의하지 않은 것으로 나타났다.

만 5세 유아의 경우, 친사회적 행동에 대한 의도적 통제의 주효과 $(t=3.98, p<.001)$ 가 유의하게 나타나 의도적 통제가 친사회적 행동에 유의한 정적 영향을 미치는 것을 알 수 있었 다(Table 5). 이는 만 5세의 의도적 통제 수준이 높을수록 친사 회적 행동을 더 많이 한다는 것을 의미한다. 또한 공감능력과
의도적 통제의 상호작용효과 역시 유의한 것 $(t=2.15, p<.05)$ 으로 나타났다. 상호작용 효과에 대한 사후 검증은 Table 6과 Figure 1에 제시하였다.

이를 보다 구체적으로 살펴보기 위해 만 5세 유아의 의도 적 통제 수준에 따른 조건부 효과를 살펴보면 Table 6과 같다. 먼저, 의도적 통제가 높은 수준인 집단 $(+1 S D)$ 에서 공감능력 이 친사회적 행동에 미치는 영향이 $b=.57$ 로 유의하였다 $(p<$ .01). 즉, 의도적 통제가 높은 수준인 집단은 $95 \%$ 신뢰구간 내 에서 하한값(LLCI)과 상한값(ULCI) 사이에 통계적 유의성이 없음을 의미한 0 을 포함하고 있지 않으므로 상호작용 효과가 유의하였다. 그러나 의도적 통제가 낮은 수준인 집단(-1SD)은 하한값(LLCI)과 상한값(ULCI) 사이에 0 을 포함하고 있어 상 호작용 효과가 유의하지 않았다. 이는 의도적 통제 수준이 높 은 집단에서 공감능력이 친사회적 행동에 정적인 영향을 미치 지만, 의도적 통제 수준이 낮은 집단에서는 공감능력이 친사 회적 행동에 미치는 영향이 유의하지 않다는 것을 의미한다.

더 구체적으로 조건부 효과의 유의영역을 살펴보기 위해 
Table 6

The Conditional Effect: Effortful Control in the Relationship Between Empathy and Prosocial Behavior Among 5-Year-Olds

\begin{tabular}{|c|c|c|c|c|c|}
\hline Effortful control & $b$ & $S E$ & $t$ & LLCI & ULCI \\
\hline$-1 S D$ & -.11 & .24 & -.45 & -.59 & .37 \\
\hline$M$ & .23 & .16 & 1.50 & -.08 & .54 \\
\hline$+1 S D$ & .57 & .20 & $2.84^{* *}$ & .17 & .98 \\
\hline
\end{tabular}

Note. $n=90$.

${ }^{* *} p<.01$.

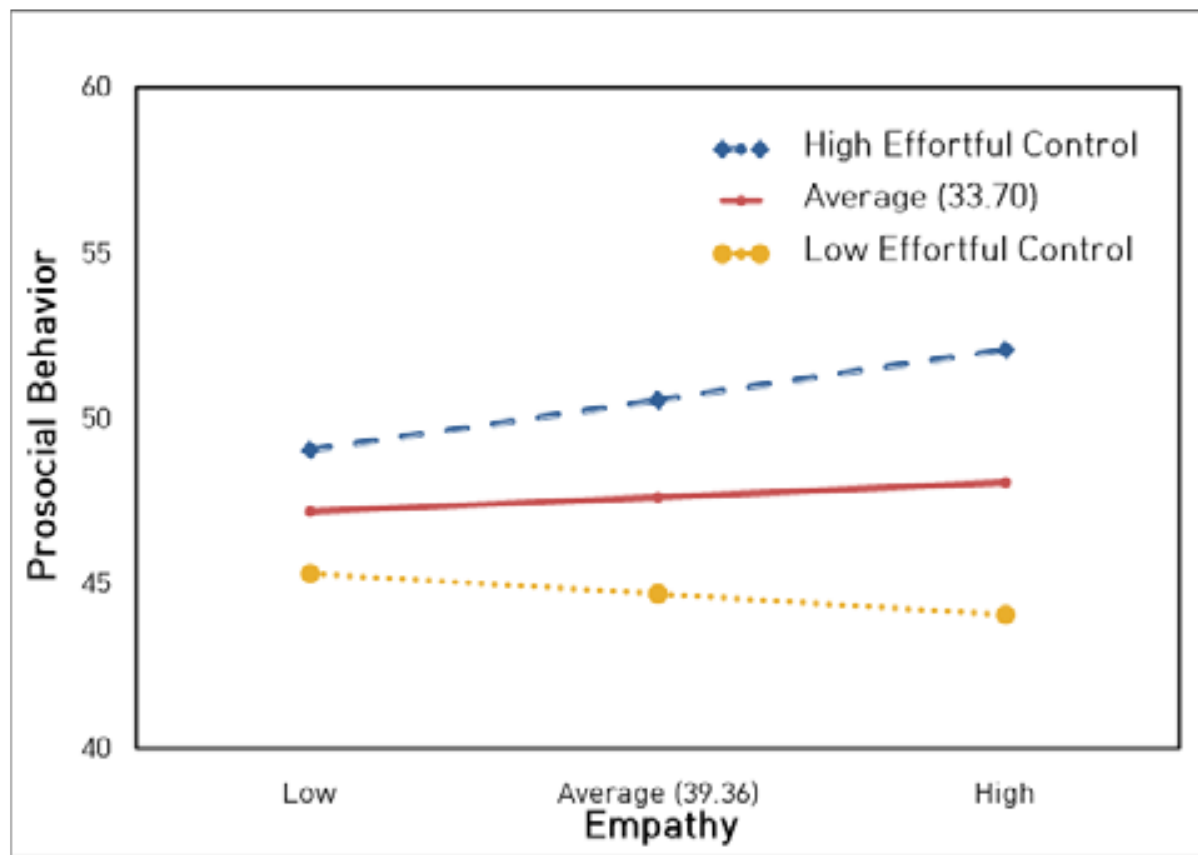

Figure 1. The interaction effect of empathy and effortful control on prosocial behavior among 5-year-olds.

Johnson-Neyman 검정 결과를 살펴보았다(Figure 1). 그 결과, 의도적 통제의 값이 33.70 이상일 경우의 조건부효과가 유의 한 것으로 나타났다. 이는 의도적 통제 수준이 평균보다 높을 때, 공감능력이 친사회적 행동에 미치는 영향이 유의미하는 것을 의미한다.

\section{Discussion}

본 연구에서 만 4,5 세 유아 간의 친사회적 행동의 수준의 차 이는 유의하지 않았다. Eisenberg, Huerta와 Edwards (2012)는 누군가 자신을 관찰하고 있다는 것을 의식하지 않는 자연스러 운 상황에서는 단순히 연령에 따라 친사회적 행동의 증가가 이루어지지 않는다고 보고하였다. 이를 바탕으로 본 연구에 서는 유아의 친사회적 행동은 교사가 유아의 일상생활을 관찰
하였으며 그들의 연령 수준을 고려하여 평정하였기 때문에 친 사회적 행동에서 유의한 차이가 나타나지 않았다고 예측할 수 있다. 본 연구에서 연령에 따른 친사회적 행동의 유의한 차이 는 나타나지 않았지만, 연령이 높아지면서 단일 변인이 아닌 다양한 변인들이 서로 연관되어 유아의 친사회적 행동 발달에 영향을 미칠 수 있기 때문에(Y. H. Kwon, 2014) 만 4, 5세 연령 을 구분하여 살펴보고자 한다.

다음으로 만 4,5 세 유아의 공감능력의 수준을 살펴보면, 만 5세 유아의 공감능력의 수준이 만 4세보다 유의하게 높았 다. 이는 유아의 연령이 높아짐에 따라 타인을 인식하고 이해 할 수 있는 인지능력의 발달이 이루어지면서 공감능력이 발 달하였기 때문인 것(Hoffman, 2008)으로 해석할 수 있다. 또한 의도적 통제 역시 만 5세 유아가 만 4세 유아보다 통계적으로 유의한 수준에서 높게 나타났다. 이에 대해 M.-J. Kang (2016) 은 행동과 충동을 조절하고 억제하는 능력과 관련된 뇌 기능 
이 연령에 따라 성숙해지기 때문에 이러한 차이가 나타난다고 하였다. 즉, 뇌 기능의 성숙으로 인해 연령에 따른 의도적 통제 수준의 증가가 이루어는 것으로 해석해 볼 수 있다.

이와 같은 결과가 나타난 이유를 본 연구의 연구 방법과 관 련지어 좀 더 살펴보면, 유아의 담임교사가 평정한 친사회적 행동과는 달리 공감능력과 의도적 통제는 연구자가 직접 구조 화된 면접을 통해서 동일한 과제로 측정하였기 때문인 것으로 추론할 수 있다. 교사가 평정한 친사회적인 행동은 유아가 평 소에 도움이 필요한 친구에게 도움을 주는지, 또래와의 놀이 상황에서 먼저 제안하고 주어진 역할을 수행하는지 등의 행동 을 토대로 교사가 평가를 하는 것이다. 여기에는 면접과 같이 유아에게 언어로 질문을 하여 답하는 식으로 정서나 조절능력 을 평가하는 측면이 제외가 되며 교사가 유아의 연령을 고려 하여 친사회적인 행동을 하는지에 대해 평가했을 가능성도 배 제할 수 없다.

반면, 구조화된 면접을 통해 만 3-5세 유아의 공감능력을 살펴본 S. Cho (2014)의 연구에서 연령이 높아질수록 공감 능력 수준의 차이가 유의하게 나타났다. 더불어 실험과제를 이용하여 의도적 통제를 측정한 Dennis, Brotman, Huang과 Gouley (2007)의 연구에서도 만 5, 6세 유아의 의도적 통제 평 균 점수가 만 4세 유아의 점수보다 전반적으로 높게 나타났다. 이와 관련하여 H. R. Lee와 Choi (2005)는 만 3, 4세 유아는 언 어를 이해하는 능력이 부족하기 때문에 면담에서 제시된 내용 을 정확히 이해하여 적절한 반응을 할 수 없다고 하였다. 즉, 언어이해능력 혹은 낮선 상황에서의 반응과 같은 연령에 따 라 달라질 수 있는 유아의 특성들이 면접 진행방법이나 실험 과제를 이해하고 표현하는 것에 영향을 미쳐 본 연구에서 공 감능력과 의도적 통제에서 연령 차이가 나타났을 가능성을 전 혀 배제할 수는 없다. 따라서 유아의 언어능력 혹은 지능 등을 조사하여 이를 통제한 후 분석하는 방법을 사용하는 것(Bae \& $\mathrm{Lim}, 2012)$ 과 같이 면접을 통한 실험과제로 유아의 특성을 측 정할 경우에 발생할 수 있는 오류를 최소화하기 위한 노력이 필요할 것이다.

친사회적 행동에 대한 공감능력과 의도적 통제의 상호작 용 효과를 살펴보기에 앞서 측정 변인들 간 Pearson의 적률상 관분석을 통해 상관관계를 살펴본 결과, 만 4,5 세 유아의 공 감능력과 친사회적 행동은 모두 유의한 정적 상관이 있었다. 이와 관련하여 Yang 등(2007)은 타인의 마음 상태를 추론한 후, 타인의 정서를 지각하고 그 정서를 대리 경험하는 공감능 력이 친사회적 행동을 이끄는 중요 요소라고 밝혔다. 더불어 Hoffman (2008)은 자신의 정서와 타인의 정서 상태를 구분할
수 있으면 공감능력은 친사회적 행동의 동기요소가 된다고 보 고하였다. 이는 유아가 타인의 마음과 정서 상태에 공감하기 시작하면 그들을 도와주고 싶은 마음이 생기기 때문에 친사회 적 행동을 더 많이 한다고 해석할 수 있다.

연령을 구분하여 성별, 출생순위, 하루 평균 보육시간, 교사 대 유아 비율에 따른 친사회적 행동의 차이가 있는지 살펴본 결과, 만 5세 유아의 경우 성별에 따른 친사회적 행동에서만 차 이가 유의하였다. 이는 대체적으로 남아에 비해 여아의 친사회 성이 높다는 연구결과(Seo et al., 2016; Song \& Jang, 2015)와 일 치한다. 이는 성별에 따라 사회에서 기대되는 행동방식을 다르 게 습득하기에 같은 상황에서도 다른 행동을 보일 수 있으며, 이에 따라 놀이 상황에서 경쟁적인 남아보다 협동적으로 행동 하는 것을 기대되는 여아가 더욱 친사회적 행동에 민감하게 반 응을 보이기 때문이라고 해석할 수 있다(Song \& Jang, 2015).

그러나 형제 유무에 따른 친사회적 행동의 차이는 나타나 지 않았는데, 이는 여성의 취업 증가 등으로 가족 계획이 점차 변화하면서 외동아와 형제아 사이의 부모 양육 태도가 다르지 않아 아동의 사회성 발달의 차이가 없다는 선행연구의 결과 (Do \& Yoon, 2004)를 바탕으로 친사회적 행동의 차이가 유의 하지 않게 나온 이유를 추측해 볼 수 있다. 또한 어린이집 보육 시간에 따른 친사회적 행동의 차이도 유의미하지 않았는데, 이는 기관의 이용 시간이 길더라도 안정적인 가정 환경과 더 불어 보육 서비스의 질 향상으로 인해 유아의 발달수준 및 친 사회적 행동이 양호하다는 KICCE (2012)의 결과를 바탕으로 기관의 보육시간의 길이에 따른 친사회적 행동의 차이가 나타 나지 않은 이유를 유추해 볼 수 있다. 마지막으로 교사 대 유아 비율에 따른 친사회적 행동의 차이 역시 나타나지 않았는데, 이는 본 연구의 조사 시점이 1 월에 진행이 되어 약 11 개월 간 학급의 유아들이 서로 친밀해져 있기에 친사회적 행동에서 유 의미한 차이가 나지 않음을 추측해 볼 수 있다.

만 4,5 세 유아 모두에게 의도적 통제와 친사회적 행동 간 정적 상관관계가 나타났다. 의도적으로 주의를 집중하며 행 동을 조절할 수 있는 능력이 유아가 타인에게 긍정적인 행동 을 할 수 있게 이끈다는 본 연구의 결과는 행동 과제로 측정 한 의도적 통제 수준이 높은 유아일수록 높은 사회적 기술을 보인다는 선행연구의 결과와 같은 맥락에서 해석할 수 있다 (Rhoades, Greenberg, \& Domitrovich, 2009). 이러한 연구결과 를 바탕으로, 외국에서는 의도적 통제의 구성요소인 주의조절 과 억제능력을 중심으로 중재 프로그램이 개발되어 그 효과 성이 보고되고 있다. 실제로 Domitrovich, Cortes와 Greenberg (2007)에 의하면, 주의조절과 억제능력을 향상시키기 위한 훈 
련을 포함한 'Promoting Alternative Thinking Strategies (PATHS)' 중재 프로그램에 참여한 유아는 프로그램에 참여하지 않았던 유아에 비해 친사회적 행동을 포함한 사회적 유능성에서 더 높은 점수를 받은 것으로 나타났다. 따라서 국내에서도 유아 의 사회적 기술의 발달을 위해서 의도적 통제를 향상시킬 수 있는 프로그램을 모색할 필요가 있다.

만 4세 유아의 친사회적 행동에 대한 공감능력과 의도적 통 제의 상호작용 효과는 유의한 결과가 나타나지 않았으며 공감 능력의 주효과만 유의하게 나타났다. 즉, 공감능력이 독립적 으로 만 4세 유아의 친사회적 행동을 예측해 주는 변인이라고 할 수 있다. M.-R. Chung와 Choi (2016)는 5세에 비해 사회.인 지적 능력이 낮은 만 4세 유아의 경우, 자신과 타인의 정서를 구분하고 타인의 정서를 잘 이해하고 배려할 줄 아는 유아들 이 그렇지 못한 유아들보다 친사회적 행동을 더 많이 한다고 밝혔다. 이러한 선행연구들을 바탕으로, 다른 사람들과의 상 호작용 속에서 공감능력이 발달한 만 4 세 유아가 그렇지 않은 유아에 비해 친사회적 행동을 더 많이 할 수 있다는 것을 추론 할 수 있다.

동일한 분석을 만 5 세 유아에게 실시한 결과, 의도적 통제 의 주효과와 친사회적 행동에 대한 공감능력과 의도적 통제 간의 상호작용 효과가 통계적으로 유의하였다. 사후분석으로 의도적 통제의 수준을 구분하여 공감능력과의 상호작용을 살 펴본 결과, 의도적 통제의 수준이 평균보다 높은 경우에 공감 능력의 수준이 높을수록 친사회적 행동을 더 많이 하는 것으 로 나타났다. 즉, 만 5 세 유아의 경우, 타인의 정서를 느끼고 함 께 공유할 뿐 아니라 대인관계에서 자신의 욕구와 즉각적인 행동적 반응을 잘 통제하고 조절하는 유아일수록 친사회적 행 동이 발달함을 알 수 있었다.

만 5세 유아에게만 친사회적 행동에 대한 공감능력과 의도 적 통제의 상호작용 효과가 나타난 것을 두 가지 근거를 통해 살펴볼 수 있다. 먼저 본 연구에서 만 5 세 유아에게서만 의도적 통제와 공감능력이 정적 상관관계가 있는 것으로 나타났는데 이는 의도적으로 자신의 감정과 행동을 잘 조절할수록 타인에 대한 공감능력도 높게 나타난다는 것을 의미한다. 이러한 결과 는 지배적인 감정과 행동을 의도적으로 조절할 수 있는 능력이 높은 유아는 타인의 감정과 상황에 대해 타인 중심적으로 공감 하려는 경향을 보인다고 밝힌 Eisenberg 등(2006)의 주장과 맥 을 같이 한다. 즉, 의도적 통제가 발달된 유아는 즉각적인 반응 을 억제하고 상황과 맥락에 따라 주의를 상대방으로 돌릴 수 있기 때문에 자기중심적으로 행동하기 보다는 타인의 입장에 서 이해하고 감정을 더 잘 공유할 수 있다고 예측해 볼 수 있다.
이를 바탕으로 Valiente 등(2010)은 타인과의 상호작용에서 자 신의 정서를 의도적으로 상황에 적합하게 조절할 수 있는 유아 는 타인지향적인 반응을 그렇지 않은 유아들 보다 더 많이 하 기 때문에 더욱 발달된 사회적 행동을 보인다고 밝혔다. 이상 의 선행연구를 바탕으로, 상황에 맞게 자신의 감정과 행동을 조절하여 바람직하게 바꿀 수 있는 만 5세 유아의 의도적 통제 능력과 함께 다른 사람의 감정에 적절하게 반응하고 공감할 수 있는 능력이 상호작용하여 다른 사람을 돕고자 하는 친사회적 행동을 유발하였다고 추측할 수 있다.

또한 만 4세에 비해 만 5세 유아의 공감능력과 의도적 통제 의 수준이 높은 것과도 관련지어 생각해 볼 수 있다. Eisenberg 등(2006)은 타인의 감정을 이해하고 공감할 수 있는 공감능력이 높고 자신의 감정과 행동을 상황에 맞게 조절하는 데 능숙한 유 아는 그렇지 않은 유아보다 상대적으로 타인에게 도움을 제공 하는 행동을 더 많이 한다고 하였다. 이러한 결과는 유아의 친 사회적 행동을 이끌어내는 데에 있어서 공감능력만으로는 충분 하지 않으며 이와 함께 자신의 행동을 의도적으로 조절할 수 있 는 의도적 통제가 함께 작용하는 것이 중요하다는 것을 내포하 고 있다. 만 4, 5세 유아의 공감능력과 행동문제를 살펴본 K. N. Kwon (2017)과 만 4, 5세 유아의 정서지능과 친사회적 행동의 관 계를 살펴본 M.-R. Chung와 Choi (2016)는 만 5세 유아의 사회. 인지적 능력이 만 4 세 유아보다 높게 나타났다고 밝혔다.

이를 바탕으로 본 연구에서 만 4세와 유의하게 차이가 난 만 5세 유아의 타인의 정서를 바르게 인식하고 배려하는 공감 능력과 더불어 특정 상황에서 정서와 행동을 조절할 수 있는 의도적 통제가 상호작용하여 친사회적 행동에 유의미한 영향 을 끼쳤다고 추측할 수 있다. 이를 통해, 연령이 높아지면서 자 신의 감정과 행동을 잘 억제하고 조절할 수 있으며 타인의 감 정에 대해 더 잘 공감할 수 있기 때문에 사회적으로 긍정적인 행동을 더 많이 할 수 있다는 것을 추론할 수 있다. 따라서 유 아의 친사회적 행동을 효과적으로 증가시키기 위해서는 연령 을 고려한 다차원적인 접근 즉, 정서적인 이해 측면과 인지적 인 조절 측면을 함께 증진시킬 수 있는 교육을 제공하는 것이 필요함을 시사한다.

종합하면, 타인의 입장에서 생각하고 대리적으로 정서 상 태를 느껴보는 공감능력이 충동적인 정서를 억제하고 행동을 조절하는 의도적 통제와 함께 일어날 때 유아의 친사회적 행 동이 더 많이 나타날 수 있다. 즉, 공감능력의 수준이 높은 아 동도 상황에 따른 인지적 통제를 하는 데 있어 어려움을 겪는 다면 일상생활에서 타인에 대해 공감할 수 있는 능력이 친사 회적 행동으로 표현되지 못할 수 있다. 그러므로 타인을 도우 
며 위로하고 함께 협력하는 삶을 살기 위해서 상대방의 입장 을 고려하고 태도와 정서를 공유할 수 있는 유아의 공감능력 에 관심을 가지는 것도 중요하지만 이와 함께 다양한 문제 해 결 상황을 통해 의도적 통제 수준을 발달시키기 위한 훈련에 도 관심을 가져야 할 필요가 있다. 아울러 유아의 친사회적 행 동 증진을 위해 가정과 기관은 연령과 발달 특성을 고려해야 하며 이 때 유아가 타인이 어떤 정서를 느낄지를 생각해보고 자신의 상황에 맞게 의도적으로 자신의 행동을 조절할 수 있 도록 도울 수 있는 직접적인 경험을 제공하거나 이야기 듣기, 역할극, 부모와 교사의 모델링을 통한 교육 등의 간접 활동의 기회를 제공해야 할 필요가 있을 것이다.

마지막으로 본 연구의 제한점과 후속연구를 위한 제언을 하면 다음과 같다.

첫째, 본 연구에서는 서울시에 위치한 직장어린이집과 민 간유치원에 재원 중인 만 4,5 세 유아를 대상으로 연구를 진행 하였기에 본 연구의 결과를 일반화하는 데 있어 제한점을 가 지고 있다. 또한 단일 연령 반으로만 구성되어 있는 유치원과 달리 대부분의 직장어린이집의 경우, 만 3,4 세 학급을 혼합연 령으로 구성한다. 어린이집의 만 3, 4세반은 본 연구의 만 4, 5 세들이 재원하는 학급이다. 이러한 기관의 특성과 연령 집단 구성의 차이는 유아의 발달에도 영향을 미칠 수 있다(Noh \& Kim, 2011). M.-S. Kim, Yoo, Lee와 Cho (2011)는 혼합연령의 구성이 유아의 사회.인지적 발달에 긍정적 영향을 줄 수 있으 며, Ishimine, Talyer와 Bennett (2010)는 연령 집단 구성과 같은 기관의 특성은 유아의 상호작용에 영향을 미쳐 유아의 발달 에 영향을 준다고 밝혔다. 비록 본 연구에서 기관의 종류에 따 른 친사회적 행동에 있어서 통계적으로 유의한 차이가 나타 나지는 않았으나, 연령에 따른 구성 차이가 유아의 사회적 행 동에 미칠 수 있는 잠재적인 영향까지 배제했다고는 할 수 없 다. 예를 들면, 혼합연령 또는 단일연령으로의 학급 구성, 남녀 의 성비 또는 같은 연령이라도 월령에 따른 차이 등 연령과 관 련하여 각 학급의 구성에 있어서 친사회적 행동에 잠재적으로 영향을 미칠 수 있는 다른 요인들을 좀 더 구체적으로 살펴 볼 필요가 있을 것이다. 또한, 교사 대 유아 비율에 따른 친사회 적 행동도 유의한 차이가 없는 것으로 나왔는데 이는 대부분 의 유아들이 1:10 이상의 비율로 구성된 학급에 재원 중이었 기에, 사회적 행동과 관련이 있는 1:10 비율을 기준으로 상, 하 집단 간 정확한 차이 분석이 어려웠던 것으로 보인다. 따라서, 후속연구에서는 다양한 지역의 서로 다른 물리적 환경적 특성 을 지닌 더 많은 수의 유아교육기관에서 연구대상을 모집하여 유아의 사회적 행동에 영향을 미칠 수 있는 물리적 환경 요인
들의 다양성을 좀 더 확보하여 함께 분석해 본다면 기관과 학 급의 물리적 환경에 따른 차이 또한 좀 더 심층적으로 분석해 볼 수 있으리라 기대된다.

둘째, 본 연구에서 사용된 교사용 친사회적 행동 평가 척도 는 교사가 평정자로서 대상 유아를 지도한 기간, 대상 유아에 대해 갖고 있는 교사의 주관적 편견 등에 따라서 그 결과가 달 라질 수 있다는 한계를 완전히 배제할 수 없다. 이에 본 연구에 서는 한명의 교사가 여러 유아들의 친사회적 행동을 평정하였 기 때문에 발생할 수 있는 내재적 자료(nested data)의 문제점 을 bootstrap 방법을 이용하는 PROCESS (Hayes, 2013)로 보완 하고자 하였다. 더욱 신뢰도 높은 연구 결과를 얻기 위해서는 훈련된 연구자가 모든 유아의 평소 일상을 관찰하여 친사회적 행동을 평정하는 방법이 있을 것이다. 하지만 현실적으로 관 찰실이 마련되어 있는 보육기관이 많지 않으며, 관계자 외 연 구의 목적으로 수업 중에 관찰을 위해 교실에 직접 투입되는 것은 사실상 허용되기 어려운 실정이다( $\mathrm{Han}, \mathrm{Kim}, \& \mathrm{Kwak}$, 2017). 따라서 후속 연구에서는 평정자인 교사를 대상으로 평 정절차에 대해 정확히 안내하고 평정자 간 신뢰도를 확인하거 나 내재적 자료를 처리할 수 있는 통계적 방법을 고려할 필요 가 있다.

셋째, 본 연구에서 유아의 공감능력을 측정하기 위해 그림 카드를 이용하였다. 그러나 만일 유아와 연구자간 신뢰감이 제대로 형성되지 않았으면 낮선 상황으로 인하여 유아 자신 이 생각하는 대로 대답을 하지 못했을 가능성도 있을 수 있다. 또한 공감능력 검사 질문을 살펴보면, “기쁘니?”, “짜증이 나 니?”, “울고 싶니?” 와 같은 질문으로 이루어졌기 때문에 유아 가 연구자의 질문 의도를 유아가 추정하여 대답했을 가능성도 전혀 배제할 수 없다. 따라서 후속 연구에서는 여러 번의 검사 를 진행하거나 “기분이 어떨까?”와 같은 더욱 개방적인 질문 으로 유아의 공감능력을 측정한다면 보다 객관적인 평가가 이 루어 질 수 있을 것이라고 본다.

넷째, 본 연구에서 사용된 유아의 공감능력 측정도구(M.J. Kang \& Sim, 2011)는 본래 4개의 하위 영역(슬픔, 심적 부담, 기쁨, 불안)으로 구성되어 있다. 척도를 살펴보면 슬픔을 제외 하고는 각각 5 개의 문항으로 이루어져 있으며 슬픔요인은 3 문항으로만 이루어져 있다. 다른 요인과 달리 3 문항으로 슬픔 에 대한 유아의 공감능력을 측정하기에는 한계가 있다. 따라 서 후속 연구에서는 다양한 평가 원천을 바탕으로 유아의 공 감능력 중 슬픔요인을 보다 정확하고 객관적으로 측정할 수 있도록 보완되어야 할 것이다. 더불어 본 연구에서 사용된 유 아 공감능력 척도는 본래 학령기 아동을 대상으로 만들어진 
외국의 척도를 한국의 유아들에게 적합하도록 수정.번안한 것 이다. 따라서 우리나라의 문화적 특성과 현 시대 유아의 발달 적 수준에 적합한 공감능력 측정 도구의 개발과 타당도 검증 이 이루어져야 할 필요가 있다.

다섯째, 본 연구는 유아의 친사회적 행동에 영향을 미치 는 요인으로 유아의 개인 내적 요인인 공감능력과 의도적 통 제로 국한시켜 다루었다. 그러나 선행연구에 따르면 유아의 친사회적 행동은 유아의 개인적 특성뿐 아니라 부모의 양육 행동(Pastorelli et al., 2016) 또는 자연 환경에서의 활동(Acar \& Torquati, 2015) 등 다양한 상황적 맥락에 의해서도 영향을 받 을 수 있다. 그러므로 후속 연구에서는 다양한 환경적 변인을 포함시켜 종합적인 연구를 진행할 필요가 있겠다.

위와 같은 제한점에도 불구하고 본 연구가 가지는 시사점 과 의의를 요약하면 다음과 같다.

첫째, 본 연구는 만 4,5 세 유아의 공감능력, 의도적 통제, 친 사회적 행동 간의 관계가 연령에 따라 어떠한 특징을 가지고 있는지에 대하여 구체적으로 비교해 보았다. 본 연구의 결과 처럼 유아의 연령에 따라 공감능력과 의도적 통제 수준의 차 이가 나타난다는 것은 유아의 사회적 적응과 관련된 연구에서 연령에 따른 차이를 살펴보는 것이 중요한 의미를 가지고 있 음을 시사한다.

둘째, 본 연구는 친사회적 행동에 대한 공감능력과 의도적 통제의 상호작용 효과에 있어서 만 4,5 세 유아의 연령집단을 구분하여 어떠한 결과가 나타나는지 검정하였다. 이를 통하 여 유아의 연령에 따라 개입을 다르게 하는 것이 필요함을 확 인하였다. 특히 만 5 세 유아의 경우 의도적 통제와 공감능력은 상호작용 요인으로써 친사회적 행동을 증진시키는 데 효과가 있음을 보여주었다. 이러한 본 연구의 결과는 유아의 친사회 적 행동을 증진시키는 프로그램 개발에 있어 연령을 고려해야 할 필요성을 제기한다.

셋째, 본 연구에서는 유아의 공감능력과 의도적 통제를 측 정하기 위하여 부모나 교사 평정 질문지를 사용하지 않고 유 아 대상의 면접을 통해 직접 측정하였다. 이는 부모나 교사의 주관적인 판단이 포함되지 않는 유아의 공감능력과 의도적 통 제를 보다 객관적으로 측정할 수 있었다는 장점을 가진다.

넷째, 본 연구에서 유아의 의도적 통제를 측정하기 위해 뽀 로로-크롱 과제와 머리-발-무릎-어깨 과제를 이용하였다. 유 아기 동안 급격하게 발달하는 의도적 통제를 측정하기 위해서 는 월령에 따른 차이를 반드시 고려해야만 한다. 이에 본 연구 에서는 연구 대상인 만 4,5 세의 발달 특성을 고려하여 적절한 난이도의 행동 과제를 시행함으로써 도구의 변별력을 높였다.
요컨대, 이 연구 결과는 만 4세와 5세 유아의 친사회적 행동을 더욱 장려하기 위해서 우선 타인의 정서를 바르게 이해하는 공감능력을 길러 주고, 연령이 증가함에 따라 의도적 통제 또 한 중시하여 지도해야 함을 시사한다.

\section{Notes}

This article is a part of the first author's master's thesis submitted in 2018.

This article was presented at the 2019 Annual Spring Conference of the Korean Association of Child Studies.

\section{Conflict of Interest}

No potential conflict of interest relevant to this article was reported.

\section{References}

\section{In English}

Acar, I., \& Torquati, J. (2015). The power of nature: Developing prosocial behavior toward nature and peers through naturebased activities. YC Young Children, 70(5), 62-71.

Allan, N. P., \& Lonigan, C. J. (2011). Examining the dimensionality of effortful control in preschool children and its relation to academic and socioemotional indicators. Developmental Psychology, 47(4), 905-915. doi:10.1037/a0023748

Bryant, B. K. (1982). An index of empathy for children and adolescents. Child Development, 53(2), 413-425. doi:10.1111/j.14678624.1982.tb01331.x

Carlo, G., Mestre, M. V., McGinley, M. M., Samper, P., Tur, A., \& Sandman, D. (2012). The interplay of emotional instability, empathy, and coping on prosocial and aggressive behaviors. Personality and Individual Differences, 53(5), 675-680. doi:10.1016/j.paid.2012.05.022

Dennis, T. A., Brotman, L. M., Huang, K.-Y., \& Gouley, K. K. (2007). Effortful control, social competence, and adjustment problems in children at risk for psychopathology. Journal of Clinical Child \& Adolescent Psychology, 36(3), 442-454. doi:10.1080/15374410701448513

Domitrovich, C. E., Cortes, R. C., \& Greenberg, M. T. (2007). Improving young children's social and emotional competence: 
A randomized trial of the preschool "PATHS" curriculum. The Journal of Primary Prevention, 28(2), 67-91. doi:10.1007/ s10935-007-0081-0

Eisenberg, N., Fabes, R. A., \& Spinrad, T. L. (2006). Prosocial development. In W. Damon \& R. M. Lerner (Series Eds.) \& N. Eisenberg (Vol. ed.), Handbook of child psychology (6th ed., Vol. 3, pp. 9-166). Hoboken, NJ: John Wiley \& Sons.

Eisenberg, N., Huerta, S., \& Edwards, A. (2012). Relation of empathy-related responding to children's and adolescents' social competence. In Decety, J. (Ed.), Empathy: From bench to bedside (pp. 148-163). Cambridge, MA: The MIT Press.

Gouley, K. K., Brotman, L. M., Huang, K. Y., \& Shrout, P. E. (2008). Construct validation of the social competence scale in preschool-age children. Social Development, 17(2), 380398. doi:10.1111/j.1467-9507.2007.00430.x

Hayes, A. (2013). Medication, moderation, and conditional process analysis. New York: Guilford Press.

Hoffman, M. L. (2002). How automatic and representational is empathy, and why. Behavioral and Brain Sciences, 25(1), 38-39. doi:10.1017/s0140525x02410011

Hoffman, M. L. (2008). Empathy and prosocial behavior. In M. Lewis, J. M. Havilland-Jones, \& L. F. Barrett (Eds.), Handbook of emotions (3rd ed., pp. 440-455). New York: Guilford Press.

Ishimine, K., Tayler, C., \& Bennett, J. (2010). Quality and early childhood education and care: A policy initiative for the 21st century. International Journal of Child Care and Education Policy, 4(2), 67-80. doi:10.1007/2288-6729-4-267

Johnson, P. O., \& Neyman, J. (1936). Tests of certain linear hypotheses and their application to some educational problems. Statistical Research Memoirs, 1, 57-93.

Kochanska, G., Barry, R. A., Jimenez, N. B., Hollatz, A. L., \& Woodard, J. (2009). Guilt and effortful control: Two mechanisms that prevent disruptive developmental trajectories. Journal of Personality and Social Psychology, 97(2), 322-333. doi:10.1037/ a0015471

Kostelnik, M. J., Whiren, A. P., Soderman, A. K., \& Gregory, K. (2006). Guiding children's social development: Theory to practice (5th ed.). New York: Thomson Delmar Learning.

Lane, J. D., Wellman, H. M., Olson, S. L., LaBounty, J., \& Kerr, D. C. (2010). Theory of mind and emotion understanding predict moral development in early childhood. British Journal of Developmental Psychology, 28(4), 871-889. doi:10.1348/026151009x483056

Leiberg, S., \& Anders, S. (2006). The multiple facets of empathy: a survey of theory and evidence. Progress in Brain Research, 156, 419-440. doi:10.1016/s00796123(06)56023-6
Lengua, L. J., Moran, L., Zalewski, M., Ruberry, E., Kiff, C., \& Thompson, S. (2015). Relations of growth in effortful control to family income, cumulative risk, and adjustment in preschool-age children. Journal of Abnormal Child Psychology, 43(4), 705-720. doi:10.1007/s10802-014-9941-2

Lieberman, M. D. (2007). Social cognitive neuroscience: A review of core processes. Annual Review of Psychology, 58, 259-289. doi:10.1146/annurev.psych.58.110405.085654

Liew, J. (2012). Effortful control, executive functions, and education: Bringing self-regulatory and social-emotional competencies to the table. Child Development Perspectives, 6(2), 105-111. doi:10.1111/j.1750-8606.2011.00196.x

McClellan, D. E., \& Katz, L. G. (2001). Assessing young children's competence. Retrieved from ERIC database. (ED450953)

McClelland, M. M., Cameron, C. E., Connor, C. M., Farris, C. L., Jewkes, A. M., \& Morrison, F. J. (2007). Links between behavioral regulation and preschoolers' literacy, vocabulary, and math skills. Developmental Psychology, 43(4), 947-959. doi:10.1037/0012-1649.43.4.947

Murray, K. T., \& Kochanska, G. (2002). Effortful control: Factor structure and relation to externalizing and internalizing behaviors. Journal of Abnormal Child Psychology, 30(5), 503-514.

Noten, M. M. P. G., Van der Heijden, K. B., Huijbregts, S. C. J., Van Goozen, S. H. M., \& Swaab, H. (2019). Indicators of affective empathy, cognitive empathy, and social attention during emotional clips in relation to aggression in 3-yearolds. Journal of Experimental Child Psychology, 185, 35-50. doi:10.1016/j.jecp.2019.04.012

Pastorelli, C., Lansford, J. E., Kanacri, B. P. L., Malone, P. S., Di Giunta, L., Bacchini, D., . . . Sorbring, E. (2016). Positive parenting and children's prosocial behavior in eight countries. Journal of Child Psychology and Psychiatry, 57(7), 824-834. doi:10.1111/jcpp.12477

Ponitz, C. E. C., McClelland, M. M., Jewkes, A. M., Connor, C. M., Farris, C. L., \& Morrison, F. J. (2008). Touch your toes! Developing a direct measure of behavioral regulation in early childhood. Early Childhood Research Quarterly, 23(2), 141-158. doi:10.1016/j.ecresq.2007.01.004

Rhoades, B. L., Greenberg, M. T., \& Domitrovich, C. E. (2009). The contribution of inhibitory control to preschoolers' socialemotional competence. Journal of Applied Developmental Psychology, 30(3), 310-320. doi:10.1016/j.appdev.2008.12.012

Rothbart, M., \& Bates, J. (2006). Temperament. In W. Damon \& L. M. Richard (Series Eds.) \& N. Eisenberg (Vol. Ed.), Handbook of child psychology (6th ed., Vol. 3, pp. 99-166). Hoboken, NJ: John Wiley \& Sons.

Rothbart, M. K., \& Rueda, M. R. (2005). The development of effortful control. In M. I. Posner (Ed.), Developing individuality in the human brain: A tribute to Michael I. Posner (pp. 167-188). 
Washington, DC: American Psycholgical Association.

Rothbart, M. K., Sheese, B. E., \& Posner, M. I. (2007). Executive attention and effortful control: Linking temperament, brain networks, and genes. Child Development Perspectives, 1(1), 2-7. doi:10.1111/j.1750-8606.2007.00002.x

Spinrad, T. L., Eisenberg, N., Gaertner, B., Popp, T., Smith, C. L., Kupfer, A., Greving, K., Liew, J., \& Hofer, C. (2007). Relations of maternal socialization and toddlers' effortful control to children's adjustment and social competence. Developmental Psychology, 43(5), 1170-1186. doi:10.1037/0012-1649.43.5.1170

Valiente, C., Lemery-Chalfant, K., \& Swanson, J. (2010). Prediction of kindergartners' academic achievement from their effortful control and emotionality: Evidence for direct and moderated relations. Journal of Educational Psychology, 102(3), 550-560. doi:10.1037/a0018992

Zhou, Q., Chen, S. H., \& Main, A. (2012). Commonalities and differences in the research on children's effortful control and executive function: A call for an integrated model of self-regulation. Child Development Perspectives, 6(2), 112121. doi:10.1111/j.1750-8606.2011.00176.x

\section{In Korean}

Bae, Y. J., \& Lim, J. Y. (2012). Factors affecting preschooler's prosocial behavior and cognitive problem-solving ability: Focusing on the parents' and preschooler's effortful control, and affectionate parenting behavior. Korean Journal of Child Studies, 33(3), 1-22. doi:10.5723/KJCS.2012.33.3.1

Cho, E., \& Jung, Y. (2014). The effects of effortful control and empathy of children on their prosocial behavior. The Korean Journal of the Human Development, 21(4), 129-147.

Cho, S. (2014). The relationship among mother's verbal control modes, children's empathy, and adjustment to preschools. Early Childhood Education o Care, 9(1), 243266. doi:10.16978/ecec.2014.9.1.010

Choi, H. H. (2014). A study on behavior problems of young children at regular classes and extended classes of childcare centers (Master's thesis). Retrieved from http://www.riss.kr/ link?id=T13375453

Choi, J. A. (2015). Study on the empathic situations and behaviors of 3-year-old children in the classroom. Korean Journal of Child Education and Care, 15(4), 67-92.

Choi, S. (2002). A study on relationship between a linguistic type of father and young children's empathic level (Master's thesis). Retrieved from http://www.riss.kr/link?id=T8605917

Chung, K.-S., \& Lee, E.-H. (2017). The effects of socio-demographic variables and maternal community living competence on young children's prosocial behavior. Journal of Educational Innovation Research, 27(2), 49-77. doi:10.21024/ pnuedi.27.2.201706.49

Chung, M.-R., \& Choi, K.-H. (2016). The influence of 4 to 5 year-old children's emotional intelligence on pro-social behavior and environment-friendly attitude. Korean Journal of Children's Media, 15(1), 29-54. doi:10.21183/ kjcm.2016.03.15.1.29

Do, M. H., \& Yoon, J.-Y. (2004). Parental rearing attitude perceived by the only children and sibling children and socio-emotional development. Korean Journal of Child Studies, 25(3), 75-85.

Han, E.-H., Kim, Y.-S., \& Kwak, K.-H. (2017). The effect of block play with pre-drawing and photography on spatial ability and spatial representational ability of four-year-old children. Korean Journal of Children's Media, 16(4), 81-106. doi:10.21183/kjcm.2017.12.16.4.81

Hwang, Y.-S. (2010). Relationship between young children's behavior and their early school adaptation in half-day program and full-day program. Korean Journal of Children's Media, 9(2), 187-203.

Jang, H. E., \& Kim, C. K. (2017). The mediating effects of mother's emotional intelligence and empathy ability between parenting stress and children's prosocial behavior. Journal of Emotional \& Behavioral Disorders, 33(2), 65-81.

Jang, Y., Kang, K., \& Kim, H. (2003). The effect of parenting style on children's prosocial behavior. Korean Journal of Child Studies, 24(4), 41-53.

Ji, K.-J., \& Lee, K. (2009). Preschoolers' behavior regulation assessed by head-to-toes task and social adjustment. Korean Journal of Child Studies, 30(6), 591-605.

Kang, M.-J. (2016). An exploration on the development of inhibition, cognitive empathy, emotional empathy and prosocial behavior of young children. Journal of Learner-Centered Curriculum and Instruction, 16(9), 1-22. doi:10.22251/ jlcci.2016.16.9.887

Kang, M.-J., \& Sim, M. (2011). The relationships between mothers' parental intelligence and children's abilities of self-control and empathy. Korean Journal of Child Studies, 32(4), 203-216.

Kim, H.-S. (2010). The effects of mothers' parenting behavior frequency and parental demand for mature behavior on their preschoolers' prosocial behaviors. Korea Journal of Child Care and Education, 64, 155-177.

Kim, H. S. (2015). The effects of maternal emotional expressiveness, maternal attitude toward preschooler's emotional expressiveness, and preschooler's effortful control on the kindergarten adjustment (Doctoral dissertation). Retrieved from http:// www.riss.kr/link?id=T13819197

Kim, M.-S., Yoo, J.-Y., Lee, M.-J., \& Cho, H.-R. (2011). Effects of classroom age composition and playfulness on children's play behavior. The Journal of Korea Open Association for 
Early Childhood Education, 16(1), 451-471.

Kim, S.-H. (2015). Teacher-child relationships and young children's prosocial behaviors. Korean Journal of Early Childhood Education, 17(3), 1-28. doi:10.15409/riece.2015.17.3.1

Kim, Y.-O. (2003). A study on the development of prosocial behavior scale for young children. Korean Journal of Child Studies, 24(5), 105-118.

Koo, J. E., \& Park, K. J. (2018). Parenting profiles and children's social skills: The mediating role of effortful control. Korean Journal of Child Studies, 39(1), 89-101. doi:10.5723/ kjcs.2018.39.1.89

Korea Institute of Child Care and Education. (2012). Readdressing the influence of time spent in child care services on child development through analysis of cortisol levels (Report No. 2012-09). Retrieved from KICCE website: http://www. kicce.re.kr

Korea Institute of Child Care and Education. (2016). Strategies for improving the environment of ECEC: exploring the most appropriate ratio of teachers vs. children (Report No. 201612). Retrieved from KICCE website: http://www.kicce. re.kr

Kwak, K. J. (2016). Developmental perspectives. Seoul: Hakjisa.

Kwon, K. N. (2017). The influence of young children's affective and cognitive empathy and peer competence on behavioral problems. Korean Journal of Child Studies, 38(1), 217-231. doi:10.5723/kjcs.2017.38.1.217

Kwon, Y. H. (2014). Children's social competence: Effects of negative emotionality, shyness and effortful control. Korean Journal of Child Education and Care, 14, 215-235.

Lee, H. R., \& Choi, B.-G. (2005). The relation between preschoolers' individual and parents' characteristics and preschoolers' emotional understanding and regulation. Family and Environment Research, 43(5), 1-14.

Lee, K.-S., Kim, S.-H., \& Kim, M.-J. (2010). The influence of a child's gender and age and familysocio-economic factors on maternal parenting styles and a child's sociality. Korean Journal of Early Childhood Education, 30(4), 187-212. doi:10.18023/kjece.2010.30.4.009

Lee, Y., \& Lim, J. (2014). The moderating effect of maternal emotion-related socialization behaviors on the relations between preschooler's effortful control and prosocial behavior. Korean Journal of Human Ecology, 23(6), 11411154. doi:10.5934/kjhe.2014.23.6.1141

Ministry of Education and Science Technology. (2013). Nuri curriculum contents by age of 3 to 5 years. Retrieved from Korean Childcare Promotion Institute website: https:// www.kcpi.or.kr

Ministry of Health \& Welfare. (2018). Boyuktonggye [보육통 계]. Retrieved from Central Support Center for Childcare website: https://central.childcare.go.kr
Moon, Y.-S. (2004). The effects of parent-child interaction by type on children's empathy, perspective-taking $\&$ prosocial behavior. Korean Journal of Early Childhood Education, 24(1), 115-143.

Noh, E. H., \& Kim, J. J. (2011). Comparative study on the operating status of full-day class in kindergarten and childcare center. Korean Journal of Child Education and Care, 11(3), 107-125.

Park, H. E., \& Park, J. H. (2017). The effects of child maltreatment from parents on reactive aggression among upper-elementary-school students and the moderating role of effortful control. Korean Journal of Child Studies, 38(5), 5-17. doi:10.5723/kjcs.2017.38.5.5

Seo, S. (2006). A study of children's pro-social behavior: Children's language development, requestive strategies, and maternal socialization beliefs and strategies. The Journal of Korea Open Association for Early Childhood Education, 11(4), $287-$ 310.

Seo, S., Beon, M. J., \& Ha, J. Y. (2016). The moderating effects of child-teacher relationships on the relation between emotional intelligence and pro-social behaviors in preschoolers. Korean Journal of Child Education and Care, 16(4), 245-270. doi:10.21213/kjcec.2016.16.4.245

Song, S. H., \& Jang, K. E. (2015). The relationship between a child's affective empathy, a mother's empathy, and the child's prosocial behavior. Korean Journal of Child Studies, 36(3), 59-75. doi:10.5723/KJCS.2015.36.3.59

The Korean Society of Educational Psychology. (2009). Terminology of education psychology. Seoul: Hakjisa.

Yang, H., Kim, H.-R., Kim, K., Koo, J., Park, E.-H., \& Jung, M.S. (2007). Young children's changing understanding of desires and emotions. The Korean Journal of Developmental Psychology, 20(3), 1-18.

Yeon, J. Y. (1988). A study on empathic development in Korean children. Korean Journal of Child Studies, 9(2), 29-59.

Yoon, J. (2015). The relationship between parenting stress and behavior and young children's peer competence (Master's thesis). Retrieved from http://www.riss.kr/link?id=T13692718

\section{ORCID}

Sori Mok http://orcid.org/0000-0002-3395-0278

Min Ju Kang http://orcid.org/0000-0002-1881-8076

Received June 30, 2019

Revision received September 15, 2019

Accepted October 7, 2019 